\title{
Shadows in a Petrifying City
}

Paweł Mościcki 


\section{Shadows in a Petrifying City}

DOI:10.18317/td.2018.en.1.10
This text came about within a project financed by the Polish National Science Centre from funds granted on the basis of decision no. DEC2011/03/B/HS2/05729. an avalanche fell upon our heads made of granite gravel granules

Tadeusz Różewicz ${ }^{1}$
It may well be that all directors try in their films - each in turn and all together - to create their own, specific blueprint which could express their attitude towards the world and to cinema itself. Just as philosophers continue to think and remain faithful to one idea despite the multiplicities and diversities of their interests, filmmakers too, while piecing their pictures together from many different elements, are actually searching for the same blueprint throughout. According to Pascal Bonitzer, what Michelangelo Antonioni is seeking in his works is "an empty, desolate shot."2 His cinema continually revolves around

1 Tadeusz Różewicz, "avalanche," trans. Joanna Trzeciak, accessed March 24, 2017, http://littlestarjournal.com/blog/2011/o2/rozewicz-comes-to-america-ii//.

2 Pascal Bonitzer, Le champ aveugle. Essais sur le réalisme au cinéma (Paris: Cahiers du Cinéma, 1999), 62. Here and further: where the original French texts are cited, the quotations are translated into English from the author's translation.

\section{Paweł Mościcki -}

philosopher, essayist, translator; works at the Institute of Literary Research of the Polish Academy of Sciences. $\mathrm{He}$ is the editor of the online academic journal „View. Theories and Practices of Visual Culture" (pismowidok.org). His recent books include: Snapshots from the Tradition of the Oppressed (2017), Chaplin. The Prevision of the Present (2017). 
abstraction, a frame that marks the emptiness in its space. The Italian director is therefore, as José Moure puts it, the creator of the original "poetics of emptiness," designating both the type of film space, identity of the character or construction of the narrative, and the very way of organising the field of vision. ${ }^{3}$

Yet the poetics of emptiness in Antonioni's work has nothing to do with transience, lightness or ephemerality. It is rather a poetics based on an emptiness that weighs a lot; one of overloading that smothers and suffocates. However paradoxical it may sound, Antonioni's emptiness is one that results from a fullness that rather floods meanings and inhibits characters' movements than exposes them to a free landscape ready to settle. In other words, this emptiness is one more of stone than of air.

Antonioni's film practice means that the emptiness is also - or perhaps above all - contained in a frame full to the brim, populated by human shadows roaming aimlessly around the urban wilderness. For a fuller argument for considering the weight of stone in the poetics of emptiness we might take the scene from La notte [The Night], in which Lidia suddenly leaves an event promoting Giovanni's book to go for an aimless walk around the city. This is certainly one of the classic measures that Antonioni takes in his films to slow down and distract the narrative. In terms of any conception of action, this sequence is practically empty, even though not lacking in events. At the same time, as the protagonist visits the city's empty streets or its secondary spaces, we see her own sense of being lost, desire to escape her previous existence, and (as we will later learn) the slow death of her emotional relationship with her husband. But it seems to be no coincidence that Antonioni follows Lidia's steps, showing her constantly rubbing against the stone walls of the buildings surrounding her and roaming around the concrete maze. A number of shots depict her as a tiny figure in the corner of a frame that is almost entirely filled with a heavy and impermeable wall of housing blocks. The emptiness here - existential, psychological, narrative and visual - is in fact an emptiness of ossified minerals, while filming it recalls grisaille painting, in which the chiaroscuro of a drawing comes incessantly closer to a stone relief.

\section{The Complex Modality of Sight}

One of the most general - and also striking - interpretive keys of Antonioni's entire film poetics is Pier Paolo Pasolini's category of "free indirect speech," as a principle not so much of narrative as of sight fashioned by his works. In Deserto rosso [Red Desert], for example, we look at the world as if we were reading a novel written in free indirect speech.

3 See José Moure, Vers une esthétique du vide au cinéma (Paris: L'Harmattan, 2000). 
This means that the author sees the world through the eyes of his characters. Indirect speech in the cinema corresponds to something that I have called "subjectivity": meaning that the camera literally replaces the characters' eyes. [...] Antonioni freed himself from this by finding his own stylistic formula: he finally managed to perceive the world through his own eyes by identifying his delirious aesthete's view with the view of a neurotic woman. ${ }^{4}$

In one film, the presence of two points of view sharing the same space of the shot leads to their inescapable contamination, since, as Pasolini notes, these visions "are inevitably analogous, but difficult to perceive, being closely intermixed, having the same style."5 As a result, the protagonists' emotions, their subjective experience of the surrounding world, is expressed in the external elements of the picture composed by the author. From psychologically understood emotions, the picture shifts into the dimension of affect, shaped by all the elements of the film - the colour and texture of the materials, distribution of figures, pace of shots, their editing, and so on.

However, this contamination of various types of vision brings with it further consequences which are not usually mentioned (Pasolini does not refer to them either). If external objects correspond to subjective emotional states, then the characters' behaviours and emotions also become an expression of the material externality of the world. In other words, the contamination works both ways. If, as the popular view has it, the empty, desolate, and hazy landscapes that Aldo roams in Il grido [The Cry] express his inner tragedy and solitude, then the hero himself also imitates the scenery, becoming, with all the depths of his experience, an inextricable element of the wildernesses shown in it.

Antonioni's free indirect cinema therefore reveals a characteristic connection between subjectivity and objectivity, a kind of coagulation or mixture characteristic of the structure of concrete. Only thanks to this understanding of contamination can the director reach the threshold of "internal neorealism"6 to which he aspires. And only thanks to this, for example, can he conclude the dramatic hospital scene in La notte, in which Lidia and Giovanni

4 Pier Paolo Pasolini, "Je défends Le Désert rouge," in Ecrits sur le cinéma. Petits dialogues avec les films (1957-1974), trans. Hervé Joubert-Laurencin (Paris: Cahiers du Cinéma, 2000), 128-129.

5 Pier Paolo Pasolini, "The Cinema of Poetry," in Movies and Methods, vol. 1, ed. Bill Nichols (Berkeley: University of California Press, 1976), 554.

6 Michelangelo Antonioni, "A Talk with Antonioni on His Films," in The Architecture of Vision. Writings and Interviews, ed. Carlo di Carlo, Giorgio Tinazzi and Marga Cottina-Jones (Chicago: University of Chicago Press, 2007), 23. 
visit a dying friend, with the sudden appearance of a loud helicopter in the sky. Or, at the end of the opening sequence of L'eclisse following a long conversation between lovers who are splitting up, the concrete tower that stands majestically across from them. At the narrative level, these sudden manifestations of material reality remind us of the eruption of affects to which the characters are sometimes subjected to at a more individual level. Which is why they can mesh so well with each other.

In L'eclisse, the blending of the objective and the subjective corresponds to the work of the camera itself, its definition realized in the practice of every filmmaker. One subtle process returns on a number of occasions throughout the film which we might call stopping the view or the petrification of visibility. This occurs when, rather than the figure in the window whose presence we expect, an image of it on the wall appears in the frame. The viewer is therefore startled by the appearance of an unexpected figure, but simultaneously his gaze must stop at the wall; it cannot penetrate into the depths of the frame. This happens first when Vittoria returns home, switches the light on, and we (the camera is placed outside the building) see through the window not the heroine, but a figure standing in the window, on a poster hanging in her room. The second instance of this technique occurs in the flat of her neighbour Marta, when a photograph of a black woman appears by the open shutters (inside the home). This is the first shot in the new place, just after we have seen Anita and Vittoria in the window of the latter's flat. The women on the wall and the film's female protagonists appear to have some kind of fundamental connection, which the camera is seeking to imply. The open window of the camera - after all a fundamental metaphor for the entire phenomenon of the depth of field and filmic realism ${ }^{7}$ - rather than the view of the external world, reveals a wall to us, on which certain figurative representations might be visible. But the very frame then becomes rather a stone demanding a relief than a window opening onto free space.

When Vittoria first visits Piero in his flat, again the window is duplicated, except that this time we are confronted with the figure of an elderly woman looking out of the window opposite the one which the heroine approaches. Yet it looks as if one window contains the other one, meaning that the old lady would virtually take Vittoria's place. We can therefore not only be stopped by a wall, but also by the Other and his glance. Or is Antonioni suggesting that the two versions of sight blockage are by no means all that different from one another, and that the visual contact with the Other works similarly as a flat wall suddenly appearing before one's eyes?

7 On the metaphor of the window as a foundation of cinematic ideology of depth of field see Jean-Louis Comolli, Cinéma contre spectacle (Paris: Editions Verdier, 2009), 17-55. 
The tension between the depth and flatness of the screen seems to be a fundamental problem in the entire composition of L'eclisse. From the very first shots of the film, we see Vittoria, who, after spending the whole night talking to Riccardo is getting ready to tell him that she is leaving him. She stands, tired, at her desk, trying to grab a figure standing on it, but she does it as if she wanted to remove it from the screen formed by the empty picture frame in front of her. Reaching into the depth of the camera frame, this becomes a symbol of impossible liberation, because after a moment of hesitation, Vittoria withdraws her hand, as if terrified by the gravity of her attempts. Throughout the sequence in Riccardo's flat, she also draws the curtains apart, to get a view through the window; in this way to form a new frame, a new point of view on the world to replace the unsuccessful shared life with her lover. This time too, the opening proves to be an illusion, and the concrete tower ultimately revealed outside the window causes consternation to the protagonists, rather than bringing relief. That the formal strategy of stopping the viewer's gaze corresponds to the characters' emotional state is demonstrated by the fact that Vittoria and Piero are able to kiss practically only through the window pane, which minimally separates their bodies from each other, and stops their desire.

\section{The State of the World}

L'eclisse is perhaps Antonioni's most compact, dense film. Suffice is to mention that, according to the director, the project was initially comprised of two films, shot from the point of view of the two main protagonists, Vittoria and Piero. ${ }^{8}$ The alloy of Antonioni's own gaze with the characters' viewpoint that characterises his cinema could thus be multiplied, combining at least three perspectives. But the main factor that makes this film unique is that, perhaps to a greater extent than the director's other pictures, its panoramic dimension comes to the fore. In other words, it is a film that does not so much tell (however meanderingly) a story happening in the world as makes an effort to present the general state of this world. "What is today's world?" is the fundamental question that resonates in it and is at the same time the fundamental task set before cinema: to portray the world in its current form, become a window through which the whole Earth can be seen. ${ }^{9}$ However, Antonioni avoids the trap of easy objectification of the

8 Antonioni, "Interviews on films. The Eclipse," in The Architecture of Vision, 281.

9 On the links between the cinema and worldliness see Stanley Cavell, The World Viewed: Reflections on the Ontology of Film (Cambridge, MA: Harvard University Press, 1979). 
world in a "world picture" as described by Heidegger, ${ }^{10}$ since his attempt assumes a radical redefinition of the language of filmic narration, dissolving the metaphysical conditions and simplifications of the category of image. What other visual media, if not contemporary cinema, will be able to transgress what, from a philosopher's point of view, is the inexorable reification of the world in representation?

The stake that determines the success of Antonioni's undertaking is thus whether he will be able to encapsulate in his work the connection between the current state of the world and changes in the film's language, ensuring that the image of Earth will not be a conclusion distilled from the narrative, but will result from the very dynamic of the way the material is organised in the film. Some film studies scholars argue that what counts most of all in L'eclisse is not the course of events, but a certain contiguity between them, the way certain sequences of the film join together - and the motifs that appear in them rather than the cause and effect relationship between them. As Marie-Claire Ropars-Wuilleumier writes:

Vittoria's world no longer knows any continuity or change; the experience described here opens with the stopping of time, which also means the ceasing of any internal life [...]. Time no longer controls her, just as she no longer controls entities, the equivalents of things that slowly replace them instead of explaining them.11

These words could equally be applied to the entirety of L'eclisse's structure, and not only to the heroine's emotional state. The plot is suspended in a void, and it does not help to follow the flow of time. Stopping internal life also means an intensified interdependence between objects and people, the urban environment, and the affects that unfold in it.

The individual sequences in the film also seem to be rather loosely connected, while the way they are linked to form a story is almost poetic. Antonioni described his approach to composition as follows:

So, having a certain amount of material in my hands, I set out to do a montage that would be absolutely free, poetically free. And I began searching for expressive ways and means, not so much through an orderly arrangement of shots that would give the scene a clear-cut beginning and end, but

10 Martin Heidegger, "The Age of the World Picture," in Off the Beaten Track, trans. Julian Young and Kenneth Hayes (Cambridge: Cambridge University Press, 2002), 57-72.

11 Marie-Claire Ropars-Wuilleumier, "L'espace et le temps dans l'univers d'Antonioni,"Etudes cinématographiques (Michelangelo Antonioni, I'homme et l'objet) 36-37 (1964) : 115. 
more through a juxtaposition of separate isolated shots and sequences that had no immediate connection with one another, but which definitely gave more meaning to the idea I had wanted to express $[\ldots] .^{\mathbf{1 2}}$

Watching L'eclisse one also has the impression that the various shots follow one another indeterminately, or, when they do build some kind of sequence, draw attention to themselves, and strive for separation. The process of reception here therefore involves assembling in one's own vision an ever newer mosaic of shots sending in various directions and continually drawing attention to elements that are marginal to something that could potentially emerge as main narrative axis. Christian Metz noticed that Antonioni is a master at making use of dead time, lost and insignificant moments as a powerful means of expression and a tool for building complex visual structures. ${ }^{13}$ This is also the case in L'eclisse, where the comparative looseness of the individual sequences means that diverse, significant juxtapositions are multiplied, expanding the boundaries of the presented world.

John Rhym, the author of an interesting interpretation of Antonioni's film focusing on the category of affect, argues that it

refuses our grasp of not only the film's possible organization and expression of meaning but also the characters' internal specifications, such as desire and intent, on which conventional forms of character identification depend. ${ }^{\mathbf{1 4}}$

In other words, the main protagonists also seem to follow similar rules in the film as objects. They are figures revolving freely around the structure of the work and entering manifold semantic constellations with the remaining elements of the film. Antonioni therefore constructs something of a plane of horizontal proximity and contiguity of various elements without the conventional hierarchy. He seeks to portray the enigma of the current state of the world by accentuating some of these juxtapositions.

In a short letter-essay that also acts as a hommage to the director, Roland Barthes referred to his strategies for reaching the present, and sketching its current contours,

12 Antonioni, A Talk with Antonioni on His Films, 24.

13 Christian Metz, "Le cinéma moderne et la narrativité", in Essais sur la signification au cinéma, vol. 2 (Paris: Klincksieck, 1983).

14 John Rhym, "Towards a Phenomenology of Cinematic Mood: Boredom and the Affect of Time in Antonioni's L'eclisse," New Literary History 43 (2012): 480. 
your work is not a fixed reflection, but an iridescent surface over which there pass, depending on what catches your eye or what the times demand of you, figures of the Social or the Passions and those of formal innovations, from modes of narration to the use of colour. Your concern for the times you live in is not that of a historian, a politician or a moralist, but rather that of a utopian whose perception is seeking to pinpoint the new world, because he is eager for this world and already wants to be part of it. The vigilance of the artist, which is yours, is a lover's vigilance, the vigilance of desire. ${ }^{15}$

If we can discern any affection in Antonioni towards the world he depicts in L'eclisse, this would above all be a variation of attentiveness, close to affinity with detail, and anticipating the smallest movements of the situations he portrays. It is this that makes him - as noted by Gilles Deleuze, rightly but with the usual excessive resoluteness - "the only contemporary author to have taken up the Nietzschean project of a real critique of morality, and this thanks to a «symptomatologist method»."16

Antonioni in this film is then neither a historian, nor a moralist, nor even (as Barthes claimed) a utopian, but an explorer of symptoms fully concentrated on watching the fundamental transformations taking place in the world and which, with the right approach, can be discerned even in the tiniest wince of a woman's face or in the objects watched in somebody's flat.

[It was important to see] I won't say the tran s formation of our psychological and emotional attitudes, but at least the symptoms of such restlessness and such behaviour which began to outline the changes and transitions that later came about in our psychology, our feelings, and perhaps even our morality. ${ }^{\mathbf{1 7}}$

The common, critical diagnosis that Antonioni's focus in his work was the atrophy of emotions of contemporary humans is not far from the truth. The caveat that needs to be made is that he is interested rather in the conditions of the global change of affective life and its forms than the psychological afflictions of certain subjects, as well, secondly, that these conditions are most of all analysed from the point of view of symptoms - that is there, where

15 Roland Barthes, "Dear Antonioni," in Geoffrey Nowell-Smith, L'avventura (London: British Film Institute, 1997), 64. Gilles Deleuze, Cinema 2: The Time-Image (London: Athlone Press, 1999), 8.

17 Antonioni, A Talk with Antonioni on His Films, 23. 
human gestures move close to inanimate matter. This is because by definition a symptom means a kind of trace that eludes the rules of psychological identification and narrative conventions, appearing in the experience of the subject like an alien intrusion.

As Barthes notes in his essay, Antonioni's filmic modernity is

an active difficulty in following the changes of Time, not just at the level of grand History but at that of the little History of which each of us is individually the measure. [...] Each of your films has been, at your personal level, a historical experience, that is to say the abandonment of an old problem and the formulation of a new question. ${ }^{\mathbf{1 8}}$

Two levels thus come into direct contact: the most general (i.e. the state of the world) and the most minute (i.e. a symptom), leaving out the intermediate stage which usually designates the framework of a film plot and the narrative of its characters' emotions. Only through this short circuit of the general and the idiomatic can an image of modernity, and its essential, irreducible Novelty emerge. The state of the world in L'eclisse is above all a set of neighbouring elements, the loose grouping of which corresponds to the poetic structure of the film, as well as showing - in just these combinations - the new symptoms of the contemporary situation. This stability, linked to the rule of contiguity, is appositely described by Pasolini, who is otherwise very critical in his approach to this ploy:

For Antonioni, the world in which similar events and emotions exist to those he depicts in his film is an immobile, inexpressible world, an absolute system that even contains something sacred within. Fear acts in it without even being recognisable, as is the case in all natural systems: a bee does not know it is a bee, a rose does not know it is a rose, a savage does not know he is a savage. The universes of the bee, rose and savage are worlds outside of history, lasting eternally for themselves, without other perspectives than sensuous depth. ${ }^{19}$

This also concerns characters who are not aware of the essential parameters of their coexistence with others, in the world of others. And so they "content themselves with suffering, without knowing what it is." ${ }^{20}$ A characteristic

18 Barthes, "Dear Antonioni," 62-63.

Pier Paolo Pasolini," Moravia et Antonioni (La Nuit)," in Ecrits sur le cinéma, 122-123. 
dimension of the contiguous worlds of individual beings is just this: they do not realise the actual rules of this coexistence. They are like lovers sleeping alongside one another - which could be a good metaphor for the relations between women and men in almost all Antonioni's films - who, absorbed in their own dreams, forget about the corporeal proximity joining them. Yet at the same time each movement, each gesture, says something about their mutual relationship, even if it is not part of its conscious and overt tribulations.

What is most astonishing in L'eclisse, standing out and recurring in various scenes, is the human proximity to stone, and existence as a being inhabiting a world made up of concrete, tarmac, and brick. We could even say that the suspension of action (or the cessation of time) in this film, which determines its poetics, is necessary in so far as to point to the puzzle of this intimate, constant, and at the same time abstract proximity that defines the fundamental conditions of modern human existence. Even at the conclusion of the first scene, as mentioned earlier, the frame of the window in Riccardo's flat shows us a huge concrete construction in the shape of a mushroom resembling the petrified form of the atomic explosion mentioned by the newspapers in the film's final scene. The protagonists stand across from this sight, disconsolate not only at their inevitable parting, but also, no doubt, at the presence of this object in their intimate situation, dense with contrasting feelings. In the scene in which she is looking for dogs on an estate of concrete blocks, Vittoria, stumbling around in the dark, encounters an equally mysterious stone monument to a human form, at which she looks as if it represented somebody close to her or implied her own emotional petrification. From this perspective, the fact that the place of Vittoria's renewed meetings with Piero is surrounded with a pile of broken concrete panels is no longer surprising, but only highlights the persistence of this motif and its connection to the film's most important problem.

\section{The Eclipse of Affect}

We might say that the main theme of L'eclisse does not diverge from Antonioni's other works. As the director himself put it, "Eros is sick; man is uneasy, something is bothering him." 21 The essential dilemma of modernity is that people lose themselves in the excess and complexity of their own feelings, no longer identify with them, and are unable to adapt to their practical needs and social aspirations.

Today we live in a period of extreme instability - political instability, moral instability, social instability, and even physical instability. The world

21 Antonioni, A Talk with Antonioni on His Films, 34. 
around and inside us is unstable. I am making a film on the instability of feelings, on the mystery of feelings. ${ }^{22}$

One of the possible tropes of the affective crisis that Antonioni follows in his oeuvre is therefore the disturbance of the opposition between the internal and external, the contamination between affect and thing, subject and world. This corresponds exactly to the aforementioned poetics of his films in which the characters' environment expresses their emotional states, and they themselves become elements of the landscape. From a subjective angle, this contamination must lead to profound disturbances and destabilisation blocking understanding and communication.

The protagonists of L'eclisse therefore undergo a certain defiguration, losing their face in favour of what surrounds them. As Bonitzer notes, "the aim of Antonioni's cinema is to reach what is not figurative through vicissitudes illustrating the eclipse of faces, erasure of characters." ${ }^{23}$ Perhaps one of the ways of expressing this state is that on almost every occasion when the characters from his films look in the mirror, they are seized by a kind of panic, their faces contorted by a grimace of suffering. In the first scene of L'eclisse, this seems particularly strong, as Vittoria's decision to break up with Riccardo is shown through her attempt to leave the shared frame. We therefore watch a man consumed by resignation on an armchair and a woman, her back turned to the camera, who shifts to the left edge of the frame. She leaves it, but does not disappear; she comes up against a mirror showing her form (the black dress seems almost to hide the torso, revealing a face almost detached from the rest of the body), at first only to viewers, and then to herself, when she turns her gaze towards it, looking at her reflection. Vittoria reacts with disgust, and only then does she find herself in a separate frame, as the camera follows her, leaving the mirror by the side. Separation and autonomy here therefore appear to be ransomed to the break-up of her personality, loss of face and disgust with herself. The heroine makes the decision to leave her lover, but she still almost seems to be waiting for reality to verify her plans and respond in some way, confirming or ruling out this solution. What is also interesting is that immediately after the mirror scene, Vittoria, in her search for an exit from the claustrophobic imprisonment in her own reflection, goes over to the window and opens the curtain, to reveal a huge concrete structure that in the logic of the sequence almost replicates her own form reflected in the mirror.

Ibid., 20. 
Defiguration, which entails the replacement of the human subject with materiality, is of course most resonant in the film's famous final scene, in which, instead of the lovers (Vittoria this time with Piero) who have arranged to meet, we observe the mainly empty tarmac streets, the concrete walls of housing blocks, piles of panels, and other elements of the urban landscape, with occasional anonymous people. "All the shots visited by the couple appear in a similar way, but they are adjusted 'through the void', as the title of the film shows: the eclipse of the face. Nobody now appears, not even a «persona»," 24 as Bonitzer notes. This means that in the film we move from a crisis of recognition - a defiguration that implies a fear of one's own reflection and panic at the view of one's own face - to a total eclipse, in which instead of a human countenance all that is visible is an empty place filled with concrete, steel, and tarmac.

Jacques Lacan, who made the "mirror phase" (a phase when a young child recognises his mirror image) into a constitutive moment for the development of the subject, also used the concept of his eclipse in his writings.

Similarly, our subject is subjected to the vel of a certain meaning he must receive or petrification. But should he retain the meaning, the nonmeaning produced by his change into signifiers will encroach on this field (of meaning). This non-meaning clearly falls within the Other's field, though it is produced as an eclipse of the subject. ${ }^{25}$

The moment of the eclipse of the subject, which Lacan also calls alienation, appears when while speaking - especially during psychoanalysis - the subject encounters signifiers that seem alien, imposed from elsewhere, although he said them himself. There are then two possibilities: either one can find some kind of understanding of their link to the subject, or he will remain in a stupor and a sense of alienation which, in the excerpt quoted above, Lacan calls petrification. Either he agrees that present in his utterance is a tinge of nonmeaning - that is, a kind of subconscious fantasy or desire - or else this non-meaning will eternally gnaw spasmodically at the entirety of meaning protected by the subject. At the same time, however, agreeing to the fact that the apparently alien signifiers belong to the subject does not preclude the non-meaning attributed to them deriving from the Other, in other words, it determines the inevitable alienation of the subject by language. In both cases,

24 Ibid., 62.

25 Jacques Lacan, "Position of the Unconscious," trans. Bruce Fink, in Reading Seminar XI. Lacan's Four Fundamental Concepts of Psychoanalysis, ed. Richard Feldstein, Bruce Fink, and Maire Jaanus (New York: State University of New York Press, 1995), 270. 
what remains at stake in the whole tension continues to be the impossibility of full self-understanding, the subject's transparency.

The characters in Antonioni's films seem to be constantly experiencing these moments of lacking definition and suspension in which their understanding of themselves encounters radical resistance. This is why their confusion is by no means liberating, but acts as a kind of eternal and mutual petrification. As José Moure writes, "although they are not clearly determined, they are also not free. Their indefiniteness, which is not a source of freedom, acts as an alienating principle that, in detaching them from the world and denying them any control over what is happening, forces them to live in an uncertain position of withdrawal and existential distance that does not permit them either to anchor anywhere, fill their lives with meaning or realise their individuality."26

Antonioni is therefore a chronicler of modern alienation, of which the main dimension is affective life:

I have never claimed to define what I do in the cinema in a philosophical way. The word "alienation" was not invented by me; for years it has been part of European critical and philosophical terminology, from Marx to Adorno. Therefore, it expresses a real phenomenon, a concrete problem of mankind that has probably grown acute over the last few years. ${ }^{27}$

This would place the director within a long tradition of critiquing modernity as an era of alienation, except that he would understand it more in line with Lacan than with the theoreticians of Marxism. He was interested in alienation largely as a structural element of the modern affective landscape, rather than as a dimension reserved for socio-political relations.

One of Lacan's well-known statements on affect, which he presented using the example of fear, is that affect cannot be suppressed. It can be reversed, displaced, transformed, or exacerbated, but only a signifier determining a desire that the subject cannot cope with can be suppressed..$^{\mathbf{2 8}}$ Antonioni's films seem to contain something of a supplement to this question according to which affect, as a result of an excess of signifiers, can be eclipsed, becoming opaque, heavy, abstract, like the concrete walls of the buildings in which the protagonists of L'eclisse live. An affective eclipse of this kind would appear when the understanding of signifiers, attributing meanings to them, and putting them

José Moure, Michelangelo Antonioni. Cinéaste de l'évidement (Paris: L'Harmattan, 2001), 49.

Antonioni, "Preface to six films," in The Architecture of Vision, 60. 
in new contexts of the subject's life, not only do not cure the subject of his petrification, but even heighten it. This is not just about the cognitive disorientation experienced by the film's protagonists, but also about the forceful consequences stemming from the existence of intensified understanding in everyday life. The constant discursivisation of one's feelings - to which Antonioni's protagonists, particularly women, seem addicted - reduces their power, and leaves them somewhat obscured, slightly covered, at a vanishing point. These almost dormant feelings are no longer enough to form relations, which is why the only escape from their unbearable presence is petrification, or reification giving minimal support.

In one of the scenes mentioned earlier, Vittoria returns to her flat, carrying an object wrapped in paper. After a moment, this turns out to be a stone slab with the imprint of a flower. The conventional situation in which a woman returns home carrying flowers, which she then puts in a vase and places in the window to lend some more life and charm to her intimate space, is thus transported into an image of the heroine's petrification. We might also note that it expresses the extreme, primal boredom in which she is immersed. ${ }^{29}$ But it might be more correct to state that this is not so much about a picture of her feelings as the effect of her defence against their lack of clarity, confusion, and eclipse. The woman appears to live in a world in which women no longer bring flowers home, but rather their fossils - only accompanied by the latter do they not feel fear. They prefer extinction in stone to the loop of feelings which they are unable to control and, by continually analysing their various aspects, find themselves completely disorientated.

We are talking here about an eclipse rather than suppression, mostly because affects in Antonioni's film seem to be a question of difference in degree, and not of nature. We do not change a feeling into something else, but reduce its intensity, cover it with the rubble of modern life, or ravage it thanks to the objects accumulated in our homes (like Riccardo and Marta). The problem with intensifying feelings seems to be that they constantly remain at an indirect, nondescript level, without either overpowering the subject with their strength (making him certain of what he feels) or vanishing without trace (freeing up space for further experiences). In one of the final dialogues between Vittoria and Piero, this problem becomes clear:

Piero: Tell me one thing. Do you think the two of us will agree?

Vittoria: Idon't know that, Piero.

29 An interesting interpretation of L'eclisse in terms of the Heideggerian category of boredom is suggested by John Rhym, see his "Towards a phenomenology of cinematic mood," 477-501. 
Piero stands up, somewhat impatiently.

Piero: Exactly, you can't say anything else, just: I don't know, I don't know,

I don't know... So why are you dating me?

Vittoria also gets up and looks at him, perturbed by his words.

Piero: And don't try to tell me you don't know why.

Again silence.

Vittoria: I would like to not love you [at all] or love you much more. ${ }^{\mathbf{3 0}}$

If earlier Vittoria (while talking to Anita) could say "there are days when holding material, a needle, a book or a man are one and the same," 31 this is by no means because she is confusing them, but because they arouse in her the same, low degree of excitement. And perhaps this is the source of both the petrification in signifiers and the fear that it causes.

\section{Capitalism and Exaltation}

The social dimension of alienation in L'eclisse is replaced entirely by the analysis of individual emotional relations, but it returns when viewed from the affective perspective. From this point of view, something that seems particularly important is the fact that much of the film's action is set in the stock market building and the stockbroker community to which Piero belongs. This is what guarantees the presence, as Antonioni claims, of "signs of violence that are connected with money." 32 The evident presence of capitalism as a system that above all organises human emotions thus comes to the fore.

The (theoretical) aspect of capitalism that Antonioni depicts in the storyline is its capacity to destroy traditional family bonds. The first time that Vittoria comes to the stock market building is to look for her mother, who has immersed herself in market speculation in an effort to escape from an undefined threat. The therapy, of course, ends up making her illness worse, and the mother's addiction to risk complicates, or even prevents entirely, the endurance of her emotional bond with her daughter. We can therefore say that Antonioni, following the Communist Manifesto, regards contemporary capitalism as a system in which

30 Michelangelo Antonioni, "Zaćmienie" [L'eclisse], in Scenariusze, trans. Wanda Gall (Warszawa: Wydawnictwa Artystyczne i Filmowe, 1989), 205 (from the Polish translation of the screenplay). Ibid., 164 . 
all fixed, fast-frozen relations, with their train of ancient and venerable prejudices and opinions, are swept away, all new-formed ones become antiquated before they can ossify.33

Although capitalism disrupts the traditional social institutions, it is by no means the same as the process of enlightenment, rationalism, and emancipation. It is rather a step backwards on the path of progress. This is because in the place of the subject attached to eternal institutions it places the subject overwhelmed by an archaic frenzy, seeking mystic participation in the incessant circulation of money. Rather than tradition, we therefore have archaic beliefs that not only do not contradict the capitalist socialisation, but are even strengthened by it. It seems to be no coincidence that the stock market building shown in L'eclisse is reminiscent of a church, with its stone flooring, columns, and embellishments. Vittoria's mother starts her day at the stock market by pouring salt on the floor "for luck," before crossing herself, waiting for a positive turn in her fortunes: this is the magic of money ideally incarnated in superstition. And the stock market, incidentally, apart from its brokers and investors, appears to be full of elderly ladies who visit the building like devotees to a new type of church to search for the answers to their quandaries.

There is no doubt that in L'eclisse, capitalism is also a kind of religion, and one with similar characteristics to those that Walter Benjamin mentions in his text "Capitalism as Religion," unpublished in his lifetime, in which he writes:

capitalism is a pure religious cult, perhaps the most extreme there ever was. Within it everything only has a meaning in direct relation to the cult: it knows no special dogma, no theology. From this standpoint, utilitarianism gains its religious colouring. The concretization of the cult connects with a second characteristic of capitalism: the permanent duration of the cult. Capitalism is the celebration of the cult sans rêve et sans merci. Here there is no "weekday," no day that would not be a holiday in the awful sense of exhibiting all sacred pomp - the extreme exertion of worship. ${ }^{34}$

Antonioni shows the system of the new religion almost from within, patiently and insightfully portraying everyday life in the stock market building. In fact,

33 Karl Marx and Friedrich Engels, The Communist Manifesto: A Modern Edition (London: Verso, 2012), 38.

34 Walter Benjamin, "Capitalism as Religion," trans. Chad Kautzer, in The Frankfurt School on Religion: Key Writings by the Major Thinkers, ed. Eduardo Mendieta (Abingdon: Routledge, 2005), 259. 
these are the only scenes in the film depicting the intensively expressed affects and true pathos of market fever.

In this way, the director endeavours to show the essential affect associated with capitalism, the source mood and Stimmung of this system. For him, however, the fundamental affect of capitalism is not a previously known pathology, even widely reinterpreted (like schizophrenia for Deleuze and Guattari), ${ }^{35}$ but rather an exaltation, an exceptional state of feelings that cannot be defined, in spite of its extreme intensity and power of "validity." This essential void of intensive emotions is demonstrated by Piero and Vittoria's conversation on his work:

Piero: You don't like the stock exchange, do you?

Vittoria: I haven't yet worked out whether it's an office, market, or boxing ring.

Piero: To understand, you need to come often. When someone starts, he gets drawn into the game, and becomes fascinated by it.

Vittoria has started to pace around the room. She turns round, her white dress is almost like a patch of light against the dark background of the wall. Her voice is full of sadness.

Vittoria: Fascinated by what, Piero ${ }^{36}$

The proximity of people to virtual money can be seen as another juxtaposition (besides stone) that Antonioni is seeking to emphasise. The constantly changing prices of shares and index listings appear as signifiers subjecting individuals to an incessant, albeit essentially futile and empty, exaltation. The gestures of brokers - shouting over each other, endlessly running to telephones, waving their arms, and showing their suggested transactions on their fingers - express an extreme pathos that stands out completely from the rest of the film, in which the protagonists seem indolent, deadened and hollow. The montage of the shots featuring brokers makes it seem that their expressive behaviour, facial contortions, and exhortations are signs shown for some Other, whose attention they are making every effort to grab. Yet the god of this temple, in which Piero is a member (belonging both to caste of the priests and the faithful), is not a person, but the abstraction of money.

Whereas in La notte Antonioni was trying to show the slow but inexorable disintegration of the relationship of the main characters, in L'eclisse, he

35 See Gilles Deleuze and Félix Guattari, L'Anti-Oedipe. Capitalisme et schizophrénie (Paris: Editions du Minuit, 1972) ; Gilles Deleuze and Félix Guattari, Mille plateaux. Capitalisme et schizophrénie, II (Paris: Editions du Minuit, 1980). 
begins from the break-up, from which point he tries to describe the conditions of forming a new love. Moreover, the latter film is perhaps much more poignant as it completely deconstructs the myth of the beautiful beginning of an intimate relationship. In his philosophy on the "procedure" of love, Alain Badiou notes that the formation of a couple depends on an event that makes a breach in the lives of individuals, rendering their further separate existence impossible. The meeting is just such an event, in which the individual learns that there is a possibility of experiencing the world no longer as an individual, but in a pair. ${ }^{37}$ It is this birth of a new subjectivity that Antonioni appears to be observing. What he does, though, is to equate an event in the procedure of love with another one from the world of capitalist speculation: a stock market slump. It is this unexpected and severe market crash, demonstrating something of a fissure in the exchange of goods and the brokers' everyday routine, which brings Piero and Vittoria together.

However, they seem to be a couple that has not experienced any exceptional moment of meeting, perhaps as this was replaced by the impact of another order. This shift of sorts might be what is responsible for the breakdown of their love. Even in the scene of their first conversation, Antonioni places a stone column between them. Its tremendous presence maintains an imprint on the exchange of looks and then sentences, composed in the form of a shot/ counter-shot sequence, and forces the pair to lean towards each other. In the next, extremely evocative shot, Antonioni shows them together in the frame, but separated by the column, which partly obscures their profiles. From the outset, their potential love is overshadowed by the stone buttresses of the new religion that does not tolerate any exceptions and does not permit authentic events. For Piero, the crash is just another breakage to a system that otherwise works just fine, the latest feast day reserved for paying homage to the god of money. A further scene that illustrates the impossibility of a truly innovative (or at least distinctive) event in capitalism, even if (or maybe because) the subjects remain in a state of continual exaltation, involves brokers gathered in the stock market building, trying to hold a minute's silence to commemorate a colleague's death. The telephones constantly ringing in booths make it clear that this is a system that never stops, even for a moment.

The symptomatology in L'eclisse therefore illustrates the fundamental impasse in which not only the heroes of the film, but the whole world finds itself. The affects in it have been erased and petrified, and the only element that replaces them is the empty exaltation that drives the well-oiled mechanisms of capitalist exchange. All affects merge together, becoming ideally interchangeable. The film's penultimate scene - the only one in which Vittoria

37 See Alain Badiou and Nicolas Truong, Eloge de l'amour (Paris: Flammarion, 2009). 
and Piero seem satisfied - is also a bitter foretaste of the inevitable failure of their relationship.

Piero: Will we see each other tomorrow?

Vittoria nods her assent.

Piero: We'll see each other tomorrow and the day after...

Vittoria: .... and the day after, and the next day...

Piero: and the next...

Vittoria: ... and this evening.

Piero: Eight o'clock, usual place. ${ }^{\mathbf{3 8}}$

Instead of their planned meeting comes the film's famous finale, dominated by a dehumanised landscape and the slow onset of darkness. At the very moment when Vittoria and Piero's love might have been continued with new experiences, the characters disappear, giving way to empty streets, anonymous passers-by, fears of nuclear war displayed on a newspaper's front page, and most of all the lifeless matter of the city - concrete walls, tarmac roads, metal lampposts, and finally the sun, which is almost indistinguishable from the streetlights as they turn on at dusk - the system must switch to its nocturnal mode. After all, all newly formed connections get old and expire, before they can harden - not even an eclipse can prevent this.

Translation: Benjamin Koschalka

38 Antonioni, "Zaćmienie," 207. Translation modified by author. 